\title{
Challenges of Implementing an E-learning Platform in an Internet Struggling Province in the Philippines
}

\author{
Niel Francis B. Casillano* \\ Eastern Samar State University Borongan City, Eastern Samar, Philippines; nfcasillano@gmail.com
}

\begin{abstract}
Objectives: The recent improvements in the Philippine internet infrastructure by top internet service providers prompted the researcher to investigate the challenges and determine the level of acceptability in the implementation of an e-learning platform in the College of Computer Studies, Eastern Samar State University, Philippines. Methods/Statistical Analysis: Rapid Application Development model was used to develop and improve the e-learning platform. Descriptive statistics were utilized to analyze its over-all acceptability and a focused group discussion was done to determine the challenges they faced during implementation. Findings: Acceptability resulted in a grand mean of 4.67, interpreted as strongly acceptable. The result implies that the platform adhered to ISO standards in terms of its maintainability, efficiency, reliability, functionality, portability, and usability but a negative finding during the focused group interview was discovered. The interview indicated that a minimal number of students have internet access which impeded them from accessing the platform. Although an alternative locally hosted platform was provided, only a few number of the students can afford to buy devices that are needed to access the system. Application/Improvements: The e-learning platform can be utilized as an alternative learning platform. The system can also make the classroom more flexible by providing students remote access to learning materials.
\end{abstract}

Keywords: e-learning, Internet Infrastructure, Struggling

\section{Introduction}

Eastern Samar is one of the poorest provinces in the Philippines, this is primarily caused by the very low economic activities in the province. One of the services that suffer from this slack in economic activity is the provinces' internet connectivity. Internet connectivity is a vital component of many institutions and establishments, the academe being one of them ${ }^{1}$. Eastern Samar State University is the only university in the province, composed of 5 campuses; the university aims to provide excellent and quality education to its primary stakeholders, the students. An average student accesses the internet from an internet café located in various places in the provinces' capital city, Borongan City.

Those who live in remote areas have to travel to the city just to access a more stable internet connection. The slow internet connection impeded the university from implementing technologies requiring a speedy internet connection. Presently, the provinces internet connectivity has improved from $2 \mathrm{G}$ to $3 \mathrm{G}$ and even $4 \mathrm{G}$ in other places, this is primarily due to the improvements made by the top internet service providers of the country ${ }^{2}$. These improvements prompted the researcher to implement an E-learning site that can be accessed by students with or without an internet connection and assess the challenges the students encountered during the implementation of the e-learning platform thru a focused group interview. E-learning is the application of digital technology and communication to improve the teaching-learning process ${ }^{3}$.

\section{Objective}

With the improved internet service in place ${ }^{2}$, the researcher aimed to optimize MOODLE CMS in implementing an

${ }^{*}$ Author for correspondence 
E-learning Platform and rate its acceptability in terms of some ISO 9126 quality Metrics ${ }^{2,3}$. Students were also asked through a focused group discussion as to how they felt when they were using the e-learning platform.

\section{Internet Connectivity in the Philippines}

Internet connectivity have been prioritized by the government because of what it can bring to the Philippines, benefits such as a more efficient government service, globally competitive knowledge workers and empowered rural communities ${ }^{4}$.

The first internet users were able to establish connection on March 29, 1994 through the help of then Com NET Employee Benjie Tan. The first internet connection was established at the PLDT network center in Makati City via the US-based ISP Sprint. This milestone opened so many doors for the Filipino people to improve virtually in any field of endeavor ${ }^{5}$.

In the $2^{\text {nd }}$ Quarter 2016 report of Akamai, a cloud service provider that publishes the status of internet connectivity of each country shows that the Philippines' internet speed averages to $4.3 \mathrm{Mbps}$ which is a little notch higher than the previous average of $3.5 \mathrm{Mbps}$ in the previous quarter report. Even at this internet speed the Philippines is still ranked last in the Asia-Pacific Region ${ }^{6}$.

\section{E-Learning in the Philippines}

Electronic Learning was a very new to Philippines Schools, although distance learning has already been practiced since 1952 though radio stations, still the Philippines was significantly lags behind other countries ${ }^{7}$.

Currently many Higher Education Institutions (HEI's) has established their own e-learning system. Most of the e-learning systems are uploaded through the internet. This places the Philippines and its students in a dilemma, because with a slack in the internet connection, how can student access e-learning sites with ease.

\section{Materials and Methods}

\subsection{Content Management System (CMS)}

The researcher used the MOODLE CMS as e-learning tool; it was customized to fit the needs of the students. An online version was uploaded through the university website and an offline version was uploaded through a local hosting architecture.

\subsection{Local Hosting Architecture}

Figure 1 shows the system architecture of the e-learning platform. Using a router, the College of Computer studies, hosted an Intranet Site. The students were provided the IP address of the site and they were able to access the locally hosted e-learning site.

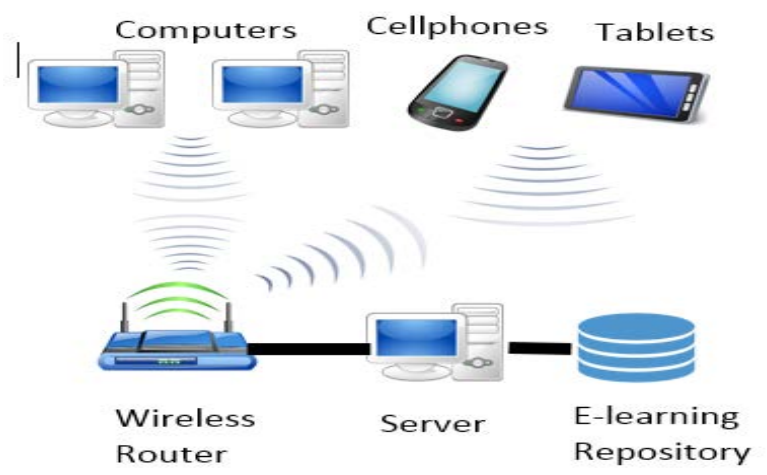

Figure 1. Local hosting architecture.

\subsection{Internet Based Architecture}

The e-learning system was also uploaded in the university website as a subdomain page. Students and teachers can choose to access either the local hosting (without internet) or the internet based e-learning site.

Table 1. Rating based on ISO 9126 Parameters as perceived by Students

\begin{tabular}{|l|l|l|l|}
\hline Parameters & $\begin{array}{l}\text { Weighted } \\
\text { Mean }\end{array}$ & Interpretation & Rank \\
\hline Maintainability & 4.57 & $\begin{array}{l}\text { Strongly } \\
\text { Acceptable }\end{array}$ & 4 \\
\hline Efficiency & 4.63 & $\begin{array}{l}\text { Strongly } \\
\text { Acceptable }\end{array}$ & 3 \\
\hline Reliability & 4.38 & Acceptable & 5 \\
\hline Portability & 4.85 & $\begin{array}{l}\text { Strongly } \\
\text { Acceptable }\end{array}$ & 2 \\
\hline Usability & 4.91 & $\begin{array}{l}\text { Strongly } \\
\text { Acceptable }\end{array}$ & 1 \\
\hline Grand Mean & 4.67 & $\begin{array}{l}\text { Strongly } \\
\text { Acceptable }\end{array}$ & \\
\hline
\end{tabular}


Table 2. Summary of the responses of students during the focused group interview on how they felt when they were using the system

\begin{tabular}{|c|c|c|c|}
\hline Items Asked & Responses & Items Asked & Responses \\
\hline $\begin{array}{l}\text { Was E-learning } \\
\text { system easy to } \\
\text { access? }\end{array}$ & $\begin{array}{l}\text { - Sometimes yes but } \\
\text { sometimes the pages } \\
\text { don't load } \\
\text { - Yes, but I don't have } \\
\text { the device to access the } \\
\text { page. } \\
\text { - I don't know the differ- } \\
\text { ent parts of the site } \\
\text { - My Phone is not inter- } \\
\text { net enabled } \\
\text { - I don't have a laptop. } \\
\text { - There are times the site } \\
\text { crashes. } \\
\text { - I don't have internet } \\
\text { connection at home } \\
\text { and mobile data is too } \\
\text { expensive }\end{array}$ & $\begin{array}{l}\text { Do you think using this } \\
\text { platform will improve your } \\
\text { academic performance? }\end{array}$ & $\begin{array}{l}\text { - Yes, because the } \\
\text { resources for a par- } \\
\text { ticular subject is } \\
\text { accessible. } \\
\text { - Yes, because learning } \\
\text { will be much more } \\
\text { fun compared to a tra- } \\
\text { ditional classroom } \\
\text { - I am not sure. }\end{array}$ \\
\hline $\begin{array}{l}\text { Was the Locally } \\
\text { Hosted E-learning } \\
\text { platform easy to use? }\end{array}$ & $\begin{array}{l}\text { - Yes } \\
\text { - Yes, because I can use } \\
\text { my phone, tablet or lap- } \\
\text { top to access it. } \\
\text { - Yes, but the page doesn't } \\
\text { load immediately }\end{array}$ & $\begin{array}{l}\text { Do you think it's } \\
\text { practical that the school } \\
\text { implemented an e-learning } \\
\text { system? }\end{array}$ & $\begin{array}{l}\text { - No, because not } \\
\text { all have advanced } \\
\text { phones, tablets and } \\
\text { laptops and not all } \\
\text { have internet connec- } \\
\text { tion } \\
\text { - No because we cannot } \\
\text { afford to have internet } \\
\text { connection } \\
\text { - I think no, because } \\
\text { we're poor and can- } \\
\text { not afford for a stable } \\
\text { internet connection }\end{array}$ \\
\hline $\begin{array}{l}\text { Will you use the } \\
\text { system often? }\end{array}$ & $\begin{array}{l}\text { - For the locally hosted } \\
\text { site, yes but for the inter- } \\
\text { net based, no, because } \\
\text { we don't have internet } \\
\text { connection at home } \\
\text { - No, because we have } \\
\text { poor internet connec- } \\
\text { tion at home } \\
\text { - Yes, but because of the } \\
\text { unstable internet con- } \\
\text { nection, I might have a } \\
\text { hard time accessing it. } \\
\text { - I don't have internet } \\
\text { access and mobile data. }\end{array}$ & & \\
\hline
\end{tabular}




\subsection{Evaluation Tool}

The researcher formulated an evaluation tool based on the ISO 9126 software quality metric. Under this standard, software must possess six main qualities namely: Maintainability, Efficiency, Reliability, Functionality, Portability and Usability ${ }^{3}$. The same quality metrics were also used by 2010 in assessing their online e-learning site ${ }^{8,9}$.

\section{Results}

The following were the results of the system evaluation:

Table 1 shows an overall acceptability rating of 4.67, interpreted as strongly acceptable. This entails that the system adhered to ISO software quality standards and that the systems usability metric was rated the highest.

Table 2 shows us the summary of the responses of the students during the focused group interview. The results of the interview evidently show that although the system was deemed compliant to software quality standards, student were apprehensive in the full implementation of the e-learning system because a few number of students have stable internet connection and not all have or can afford to but devices needed in accessing the e-learning system.

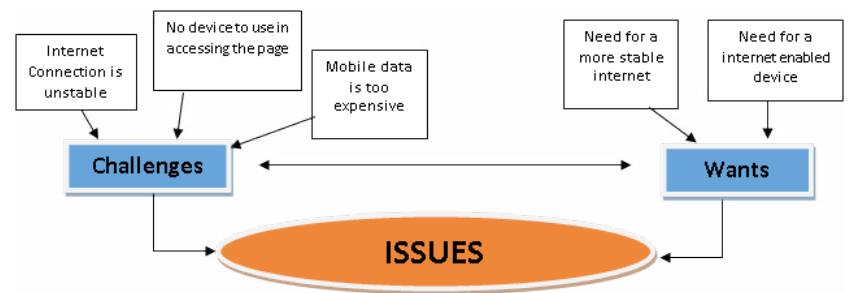

Figure 2. Emerging issues relative to the Implementation of the E-learning system.

Figure 2 shows the issues that arose during the implementation of the E-learning system. It was figured out that most of the students were able to use the system with ease but because of lack of internet facilities and internet enabled devices some of the students were not able to access the system. This issue is attributed primarily to the inability of the students to but devices and subscribe to internet services due to financial reasons.

\section{Conclusion}

Implementing an e-learning platform and keeping up with the fast-paced technology will indeed leverage the teaching-learning process, but implementing it in an internet struggling province raises many concerns. Although the system has adhered to quality metrics evident from the 4.67 rating during the system testing and the drastic improvements of Eastern Samar, Philippines' internet connectivity, a full implementation of an e-learning platform concerns many students. Based on the focused group interview not all students have internet connectivity at home and not all can afford to buy devices needed to access the said system. With this result, the researcher suggests that integrating the e-learning system in the conventional classroom and making it an option for students to access will provide flexibility to students without forcing them to buy expensive internet-enabled devices and provide their own internet connectivity.

\section{References}

1. Akamai's [State of Internet]. Cambridge, Massachusets [Internet]. [cited 2018 Aug 20]. Available from: https:// www.akamai.com/uk/en/about/our-thinking/state-of-theinternet-report/.

2. The Arangkada Philippines Project [Internet]. [cited 2017 Mar 24]. Available from: https://www.usaid.gov/philippines/partnership-growth-pfg/tapp.

3. International Standardization Organization [Internet]. [cited 2018 Nov 21]. Available from: https://en.wikipedia. org/wiki/International_Organization_for_Standardization. Date accessed: 21/11/2018.

4. Padayachee I, Kotze P, van Der Merwe A. ISO 9126 external systems quality characteristics, subcharacteristics subcharacteristics and domain specific criteria for evaluating e-Learning systems. SACLA; 2010. p. 1-9.

5. Lallana EC, Soriano C. Towards Universal Internet Access. ideaCorp and Intel Technology Philippines; 2007. p. 1-35.

6. Internet in The Philippines: 20 Years Online [Internet]. [cited 2014 Mar 20]. Available from: http://www.theurbanroamer.com/internet-in-the-philippines-20-years-online/.

7. Philippine Internet is improving but still the slowest in the world. The Philippine Star [Internet]. [cited 2016 Oct 10]. Available from: http://www.philstar.com/ technology/2016/10/10/1631885/philippine-internetimproving-still-slowest-world.

8. Arimbuyutan R, Kim S, Song JG, So W. A Study on e-Learning for Philippines. International Journal of Multimedia and Ubiquitous Engineering; 2007. p. 49-53.

9. Mahajan R, Mahajan V. Real time analysis of attributes of an Indian e-learning site. The International Journal of E-Learning and Educational Technologies in the Digital Media. 2015; 1(2):109-14. https://doi.org/10.17781/P001706 